\title{
The Effect of Public Participation in the Elections to Improve the Living Conditions of People in the Islamic Republic of Iran
}

\author{
Asghar Yazdi ${ }^{1} \&$ Majid Masomi² \\ ${ }^{1} \mathrm{PhD}$ Student, Department of Political science, Baft Branch, Islamic Azad University, Baft, Iran \\ ${ }^{2}$ Assistant Professor, Department of Political science, Baft Branch, Islamic Azad University, Baft, Iran \\ Correspondence: Majid Masomi, Assistant Professor, Department of Political science, Baft Branch, Islamic Azad \\ University, Baft, Iran. E-mail: M_masomi2002@yahoo.com
}

Received: August 28, $2016 \quad$ Accepted: September 21, $2016 \quad$ Online Published: November 30, 2016
doi:10.5539/jpl.v9n10p42

\begin{abstract}
The purpose of this research is to investigate the impact of public participation in election events on improvement of lives of people in Islamic Republic of Iran. This study is a descriptive-analytic research and was performed under field methods. The authors have elaborated on theoretical foundations of the subject and mechanisms of election in Iran. in later sections, results of the study have been investigated. With respect to analyses and investigations, it can be stated that in every democratic system, it is necessary to hold elections in order to determine the destiny of people and the country. In fact existence of people's vote regarding legitimacy of the system can result in development of the society and improvement of people's lives as well. With respect to results it can be said that in every country, holding elections seems crucially necessary and in fact a perquisite for obtaining a prosperous and democratic society is holding elections.
\end{abstract}

Keywords: participation, elections, people, Iran

\section{Introduction}

One of the easiest and least expensive ways of popular participation in political governance systems is political participation and its symbol is the elections or democracy. Election is of the highest manifestation of the people in the political arena and the main realization of the sovereignty of the people. Democracy is a system of popular sovereignty over its people's destiny i.e., the system of government of the people and government accountable to its people. Competitive elections and peaceful participation increases the sense of responsibility of the demands of society. Election increases the responsibility of rulers over demands of society. The public nature of this participation and its freedom and selective nature are the main constituents affecting people in decisions made in the frame of the legislature. On the other hand, popular system is a direct rule based on the principles of democracy. Today, thanks to popularity of Islam-based system that aims to suit the demands of the people and its value-based foundation, people have a special position among the political participation in all aspects. However, adopting the guidelines of the election law provides an opportunity for people to participate in this great task with discretion and based on a duty in the system, and to choose the right representative. This means the participation of the people based on Islamic principles.

\section{Statement of the Problem}

Election has been considered as one of the manifestations of religious democracy in the Islamic Republic of Iran. Public participation, as one of the main characteristic of developed democratic system, is the most common, easiest and lowest cost type of political participation. In the Islamic Republic of Iran, voluntary participation is considered to be the norm in such a way that people decide to participate in elections or influence on policy through non-participation. Participation in elections is seen as just one of the mechanisms of political participation. Later, they reflect their demands in public policy. Evaluating the effectiveness and role of the people is very important.

Historically, before the popular revolution in Iran, people were unaware of government performance while today at the beginning of the twenty-first century and in the shadow of the communications revolution, people are more or less aware of their role and the government and able to affect the behavior of the government. Today, people are encouraged to intervene and participate in the political process. One reason for the increase in 
people's participation in politics is public governance as a basis for legitimate political power. According to this principle, people have the right to rule and those who attempt to work, in fact, get their authority from the people. General acceptance of the principle of popular sovereignty would support the political participation of the masses norm. So if we accept the principle that political power comes from the people, in principle, people should be involved in political affairs and exercise their sovereignty. What role can citizens have in politics? Are citizens able to influence the political elite to be able to influence policy? In other words, whether there is a link between turnout and government policy.

In recent years, in line with public policy, the government's top priority is to solve the problems of the people. In this regard, people can be affected by their participation in politics. When people participate in elections and vote for a candidate program, in fact, people are prioritizing among various candidates' policies and programs. The successful candidate also proposes programs and policies according to people's attempts to apply public policy. This indicates that there is a main link between people's participation, elections and public policy. Public participation has many effects at all levels of the political process. Now the question arises if popular participation affects the political process in Iran, does it affect the improvement of living conditions of people in the Islamic Republic of Iran? In other words, what is the effect of public participation in the electoral arena on the improvement of the living conditions of people in the Islamic Republic of Iran?

\section{Public Participation}

In Persian dictionary, the term participation means "take part" and more means "doing business with each other and share its benefits" (Pishgahifard, 2007). Participation, in general, is the agreement between two or more people in the business. Each of the owners involved in the deal are personally responsible for any legal action or debt. Public participation usually arises as a result of solidarity and national unity and include effective informed consent and active participation of the community to achieve a specific goal in terms of interactivity, collaboration, cooperation and collaboration of the desire, willingness and enthusiasm by all actual and potential facilities. Accordingly, in the social system, public participation refers to mutual assistance of people and sovereignty in the implementation of development of political, economic, social programs and projects (Shiri and Khodadadpour, 2014).

In addition, public participation, as a contributing factor, has an important role in development cooperation by providing assistance and cooperation fields constantly spreading and physical development and supply needs of the public and the country's infrastructure (Gholami, 2012).

\section{The Concept of Elections}

The word "election", the Arabic verb root "Nokhab", means selection and choice. Its European equivalent, Election, goes back to the Latin verb of "Eligeve" meaning to remove, disassemble and adopt. In terms of semantics, this term has gained a wide semantic changes. However, in common usage and in general, it means the method for choosing a certain number of people from the large number of people who have been nominated to fill a position or office (Haghighi, 2001). But in a more general definition, election is an integrated and ongoing operation in a certain area and time limit, and led to the election of the person or persons or object and purpose by the majority of people (Ashuri, 2008).

From this perspective, the election is the means by which we can determine the will of the citizens in the development of political institutions and political authority in charge of the intervention (Lazar Esfeld, 2003). Voter participates in the political affairs of their community which is a political legal action. The elections, on the one hand, shows the social bases of political power and, on the other hand, it is a good criterion to evaluate the distribution of power in society (Haghighi, 2001).

\section{The Nature of Popular Participation in the Electoral Arena}

Election is the arena of public participation and represents people's power and national support of system. The more participation takes place in the election, the system will have a stronger backing and will move in its direction with strength and more power. In other words, the interpretation of the nature of public participation in this area has taken a new concept that is divided into two categories (Razi, 2002):

A) rights-based participation of people

Some people know participation in the elections a right. And in order to have sustainable society, they will choose and consider this as a legal right for themselves.

B) partnership based on a practical and Islamic duty 
Others know the participation in the election not only as a legal right to their own, but as a divine duty and on the basis of Islamic principles and religious known to the system. According to this theory, the role of such people in Islamic Iran is more than the first. And omnipresence and the epidemic will have proved their political vitality in all fields. In this type of partnership which is a political and religious all-people's referendum, people with a selection of natural selection and the origin of religion-based and provincial and reflecting the value that has the expertise and commitment, will led to secure and neutralize the enemies' conspiracies and threats (Mehregan and Ezzati, 2006).

\section{Factors Affecting Participation in the Iran's Presidential Election}

Iran has failed the topographic pattern of population structure and natural environment. This affects the pattern of formation of the nation and its peoples and nations which have created hybrid marginalized ethnic minorities. This hybrid model where the vast majority of the three-layer combination, religion (95\%), ethnicity and language (75\%) and the establishment of heterogeneity in geographical space have joined the Central Plateau of Iran has facilitated the establishment of centralized government in Iran. This type of Iranian regime pattern that has not spread geographic spatial distribution of power in the country, has not led to the political and administrative non-interference in the fate of people in the national and local levels. Due to this, the following factors are the most important factors affecting the Iranian people's participation and electoral behavior:

\subsection{The Location and Spatial Differences}

The geographical distribution of natural diversity in Iran has caused people live with different characteristics in different regions of the country. This creates spatial diversity and specific social behaviors in each of the geographic regions of Iran. Electorate is, in principle, a geographic area known legal boundaries and a certain number of representative components that form the territory of the country (Haghighi, 1991). The creation of electoral districts, in addition to geographical features and public acceptance, electoral laws, public laws and constitution have key role (Pishgahifard, 2007). The difference in public participation at polling stations in central and border parts of Iran in nine presidential elections shows different views of geographical Iranian people's participation in different places. For example: Statistical analysis of Isfahan and Yazd provinces as the central provinces of Iran and Kurdistan and Sistan-Baluchestan provinces as borders in nine presidential elections show participation rates in the border provinces has always been lower than the central provinces of Iran.

\subsection{The Human Factor and Human Differences}

The structure of society is also a major cause of human social behavior including behaviors and participation in elections. Age, gender, and religion are known to be the most important human factors in voting behavior. Political, sociological studies show that, according to the discipline and conservatism, the elderly people tend to be much more moderate and have tendency to conservative parties of young people who are inclined to the left or right radical parties (Dodarzheh, 1990). Gender is also an impressive and important factor in the election. In Iran, according to the traditional values and beliefs of women, until the mid-70s women's participation in the presidential elections were not significant (KordKarimi, 2002). Of religious aspect, the majority of Iranians are Shiites and live in the central regions of the country. Sunni minorities live in border areas and marginal provinces.

\subsection{Socio-Economic Factor}

Iran's political structure and economic functions independent of the geographical regions of the country and the government's financial relying on the sale of natural resources. And disproportionate infusion of wealth in the country, has led to form certain social classes in different geographical areas of Iran in terms of economic factors (Pishgahifard, 2007).

\subsection{Advertising-political Decision Factor}

Government and election officials provide fields of extensive presence of people in the election before the election. It depends a lot on political decisions and the amount and type of electoral campaigns by the government and political parties. In addition to political decisions, advertising is an important factor affecting the role of public participation in the elections. One of the most important tasks of political geographers in the process of elections is to determine which advertising model in which geographic regions have more applications. This would, in addition to substantially reducing the cost of advertising, will effectively help to increase women's participation in the presidential elections (ibid: 98 ). 


\subsection{The Effects of Public Participation in the Elections to Improve the Living Conditions of People in the Islamic Republic of Iran}

Increasing participation of elections can be regarded as one of the most important features of elections in each country. Based on the very foundations of democracy based on Islam is institutionalized in the Islamic Republic of Iran. Turnout in election vaccinates system and provides protection for the country. In recent years, one goal of colonizers for the secularization of Muslim societies is making them indifferent to the fate of their own social and preparation for easy control of the communities as Islam is the collection of religious, political, and spiritual affairs. But secularism is not attached to the religion with politics. With this idea, it follows the Muslims only to pray and remain unaware of the social and political affairs. Therefore, in the Shiite school, leadership thought is inseparable from the political leadership and the two have also been incorporated (Mehregan and Ezzati, 2006). The epic comes from passion, determination and unity of a nation, all of which are the characteristics of creating an epic. People can participate with a maximum presence securing the system against arrogant enemies. Then, they open the way to progress and go in a direction that is in line with the horizon and the prospects for 2025 . Second, with participation of people, people of the world, whether friend or enemy, realize that people in any circumstances support the revolution. Enemies would conclude that this revolution has popular support and can implement their plans and programs (Razi, 2002). By preventing the domination of monopolistic groups on the political and economic foundations of society and maintaining social justice, we can strengthen the motivation the desire of the public to participate in the political, economic and social. For if all things are in the hands of a particular party and government units and institutions moving in to their demand, there will be no room for the expression of popular participation. Culture is the most important variables of political and social participation. Participation in a community that has a participatory political culture is vast (Sayyed Imami and Abdulmutallab, 2009).

Arousing public trust, for the institutionalization of political behavior, change attitudes and change people's mentality and political sensitivity, people's participation is one of the desired results. As a result, arousing public participation in political formations entails the dynamics of social order and stability of sovereignty. Social and economic justice and poverty are major issues which play a decisive role in the development of political and social participation. The Quran knows social and economic justice as the social purpose behind sending prophets of God (Hadid, 25). Imam Khomeini (RH) describes religious orders as justice interface and theocracy (Imam Khomeini, 1998).

One of the functions of the media is to create social cohesion and affect the public participation. Media in society, despite the differences, contradictions and help to destroy the unity or unification of society. The media, in different ways, invite public participation including: Advertising and encouraging, motivating (Koel, 2006).

In addition, extensive presence of people in the presidential election will affect the policies of the international community. Iran presidential election may, apart from its geopolitical position, be such as the election campaign which are held in dozens of other countries and does not have much importance for the international community but Iran's position and status is important in this matter. Iran could play a role in various regional issues and focuses the world's attention to the presidential election.

Regional and trans-regional countries often are awaiting the results of the Iranian presidential election, if people move toward cooperation by maintaining principles. Other countries will treat differently. Of course, the more people participate in the election, the larger influence will have on politics and international calculations. The higher the presence of people in presidential election, the international communities are doing calculations on Iran's role in the global arena. But if the countries of the region and beyond see people dealing reluctantly with election, procedures in other countries toward Iran will be destructive. Therefore, the presence of people in the presidential election is quite impressive on policy toward Iran and other countries (Mehregan and Ezzati, 2006).

In addition, the maximum presence of people in the election is the most important factor in increasing the bargaining power of Iran. Therefore, efforts to improve people's internal affairs and a strong presence on the ground is essential. One of the manifestations of popular support, in addition to support, is the presence of people on special days and events of the campaign for self-determination. The maximum number of people in the elections, which can act as a symbol in abroad, can be effective in solving international problems in which Iran is also involved (Razi, 2002).

Voting is to defend and protect themselves against the enemy. In each country, the most important issue is national security. National security is a shield in which you live and where you have endless freedom and power. Each vote is as a brick building the national security. If the brick is not in its place, undoubtedly, the building will be permeable and will kindled the greed of the enemy. In fact, voting is to defend self and our own interests 
(Seyed-Emami and Abdulmutallab, 2009).

\section{Conclusion}

The importance of the phenomenon in the creation and representation of political legitimacy, breadth and quality of participation and response capacity of the political system extend open spaces and expand the scope of social power, and the power of intermediary institutions and, ultimately, lead to hedging the political system. Acceptance of the constitution governing the elections is a way like any other pattern. Adoption of election model, as a way of managing the country's constitution like any other pattern, needs few requirements. For this reason, basing or explaining the electoral law in which the electoral system and public participation are determined is essential. It is clear that the practical impact of public participation in reviewing the results of the elections on improving the living conditions of people in any democratic country is considered because survey feedback is required for every law in the process of completing legislation and, thus, the trend of development of a country on the path to happiness.

\section{References}

Coel, M. (2006). translated by Parviz Ejlali, theories of mass communication, Media publications.

Dorerzheh, M. (2001). sociology, translation A. Judge, Tehran, Tehran University.

Gholami, M. et al. (2012). people's participation and development case of Lamerd city in Fars province, the fifth International Congress of Islamic geographers.

Hafeznia, M. R. (2002). the political geography of Iran. Tehran, SAMT.

Haghighi, M. S. (1991). election, definitions and reform Tehran, the country's election office.

Imam Khomeini. (1998). Institute for Compilation and Publication of Imam Khomeini. Vending, vol. 2, Tehran.

Kord Karimi, R. (2002). geographical patterns. Tehran: Tehran University Center.

Lazarsfeld, P. (2003). elections, translator Mohammad Reza Rostami. Tehran, crystallization.

Nader, M., \& Ezzati, M. (2006). The impact of economic variables on the turnout in the election. Economic Research Journal, VI(1).

Pishgahi Fard, Z. (2007). research methods in political geography. Tehran, Sarallah.

Razi, D. (2001). A comparative study of social factors affecting women's participation in elections six elections after the Islamic Republic of Iran, Al-Zahra University, Volume 11, Issue 37-38.

Seyed-Emami, K., \& Abdulmutallab, A. (2009). Factors influencing participation of citizens in the presidential and parliamentary elections, Tehran Case Study. Journal of Political Science, IV(4).

Shirvai, A. H., \& Khodadadpour, M. (2014). a public-private partnership from the perspective of Iranian law, Volume 11, Number 2, Fall and Winter.

\section{Copyrights}

Copyright for this article is retained by the author(s), with first publication rights granted to the journal.

This is an open-access article distributed under the terms and conditions of the Creative Commons Attribution license (http://creativecommons.org/licenses/by/4.0/). 